\title{
CHILDE HASSAM
}

\author{
$B r$
}

CARL ZIGROSSER

$\mathrm{N}$

$4 \varnothing .1$

H35y

Z6

NMAA

FREDERICK KEPPEL \& CO.

4 EAST 39TH STREET

NEW YORK

1916 


\section{CHILDE HASSAM,}

\section{$N$}

40.1

$435 y 26$

$\checkmark M A A$

A Prefatory Note by

7. Alden Weir, and an

Appreciation and Cata-

.logue by Carl Zi.. igrosser

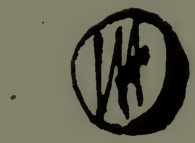

Frederick Keppel E Co.

New rork

IgI6 


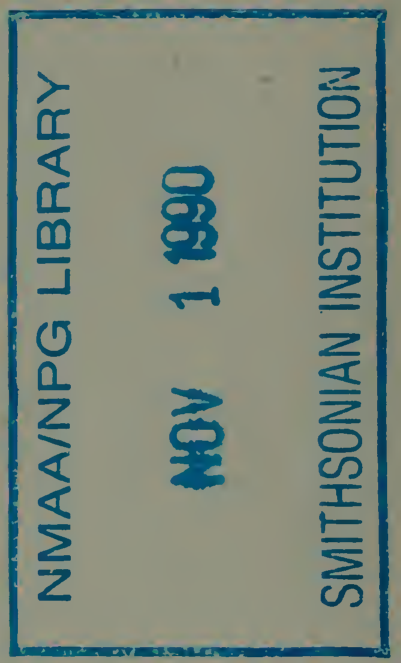




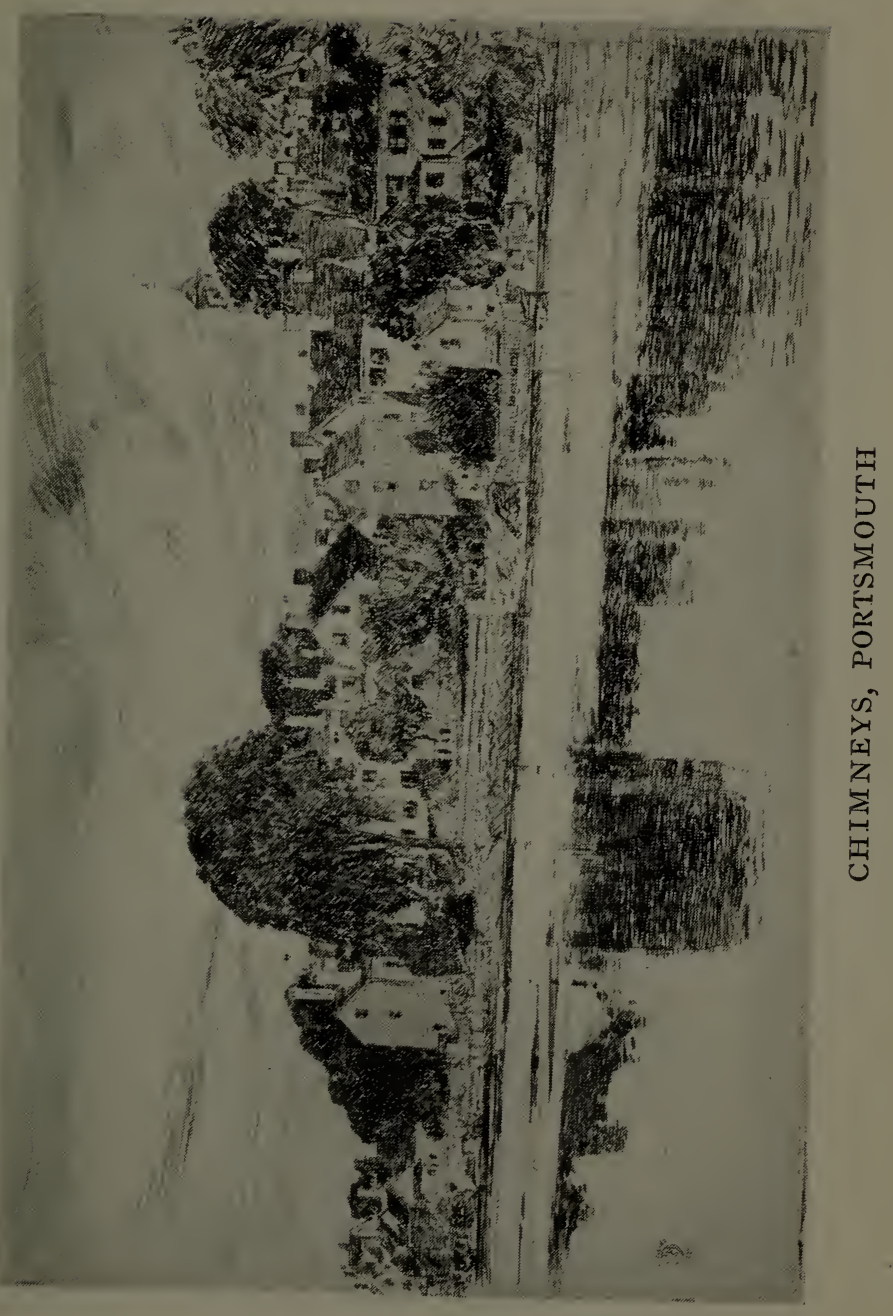





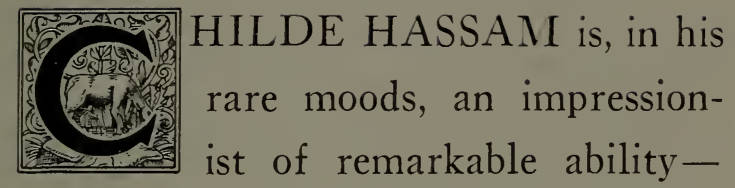
which appeals strongly to all good painters. I have always felt that so direct an observer would add a new note in etching, and I have, with others in the past several years, tried to awaken his interest in the needle. $\mathrm{He}$ now has produced in this line much that needs no words to recommend, and I heartily wish him the success that is his due.

$$
\text { J. Alden Weir. }
$$





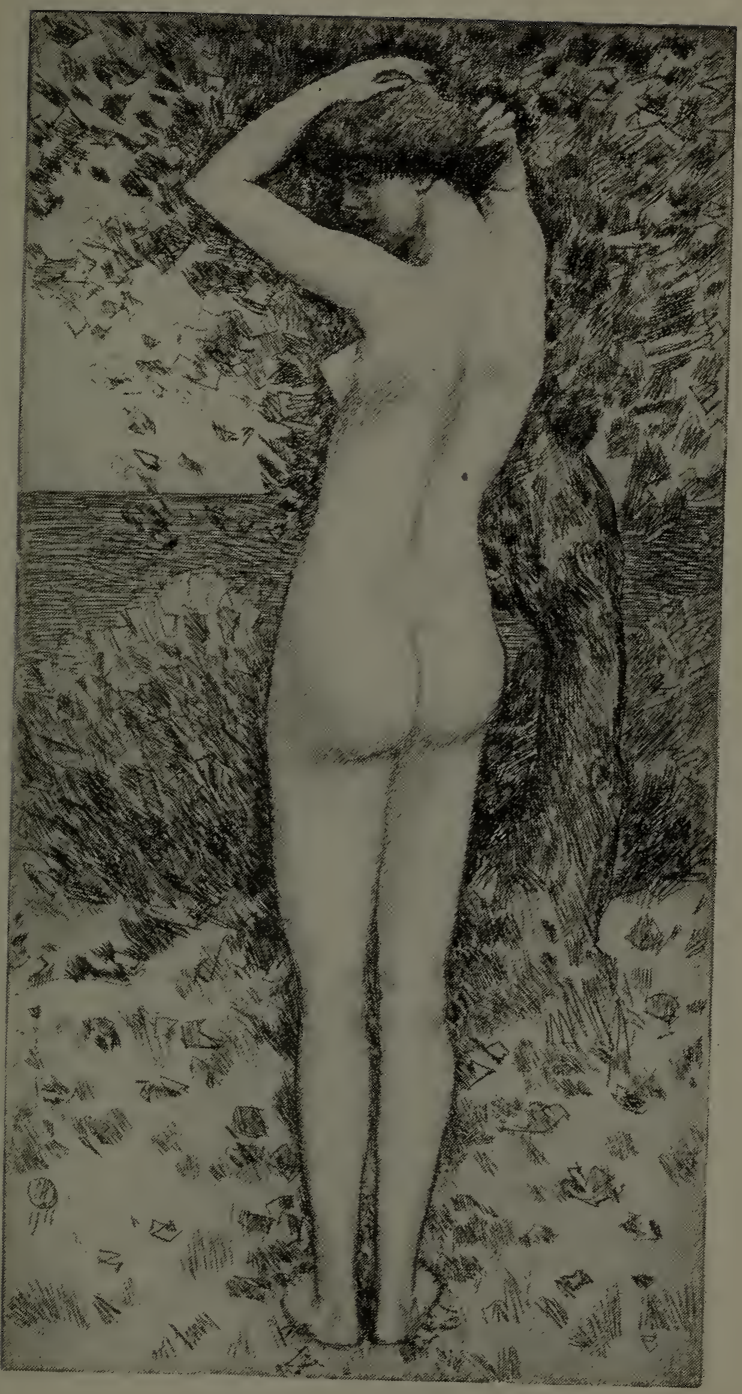

THE ALMOND TREE 



\section{Childe Hassam}

by

\section{Carl Zigrosser}

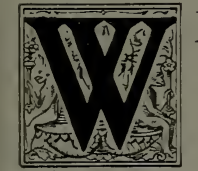

HEN an artist who has achieved success in one medium devotes himself to an entirely new field of expression a keen expectation is aroused in his audience as to how he will acquit himself. Will he, they ask, push out to the frontiers of his new medium and chisel out one more milestone of progress; will he remain true to his artistic nature and not attempt to work out his new technique with the means and methods of his old? For, after all, the hall-mark of the real artistas the achievement of Rembrandt, Whistler, Dürer, Michelangelo, and the other great ones will testify - is a certain creative prodigality that overflows the confines of a single medium, a creative exuberance coupled with a wholesome respect for the limitations of the particular medium. It is this distinction that separates the artist from the craftsman. The artist is, as it were, a mass of energy finding a perfect 
artistic expression in any number of outlets, whereas the craftsman is a body laboriously gathering momentum along one chosen path. The artist is irrepressible and joyous and daring, never quite satisfied with his achievement, in a sense rather superior to it, the divine dancer of Nietzsche's phrase. He possesses enormous funds of strength in reserve and his work always gives promise of greater work to come. The craftsman, on the other hand, spends all his strength in attaining mastery over his one craft; he never quite measures up to his medium. Take from him his one technique and he is shorn of his power.

It is with some such adventurous thrill and speculation that one examines the new etchings of Childe Hassam. But one soon discovers that it is the artist and not the craftsman who made them. He has projected his personality into one more objective medium; he has shown us one more facet of his art. Here, one feels, is a distinct individuality translated into etching. All the qualities which render his paintings so delightful are reflected in his etchings - sensitiveness to beauty of still life, to grace of gesture, to motives of decoration and arrangement, 


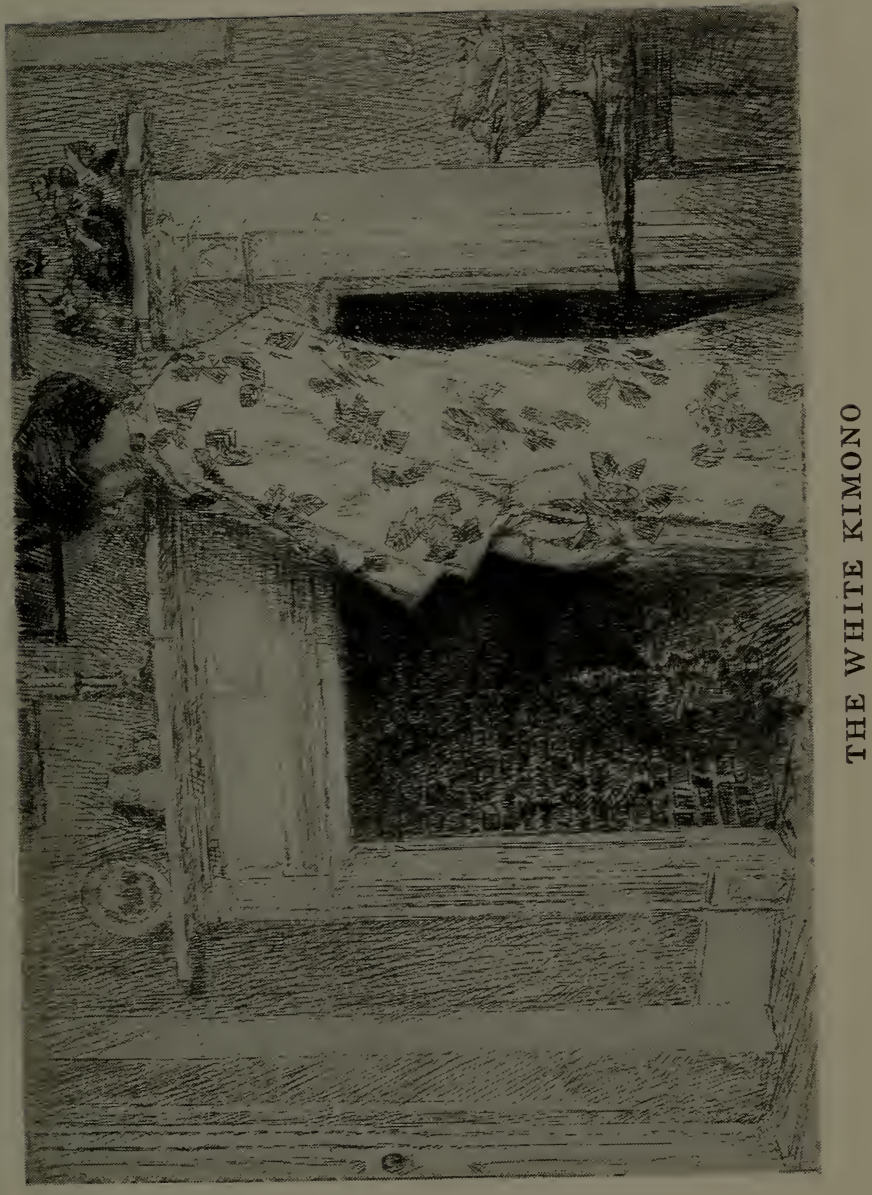


1 


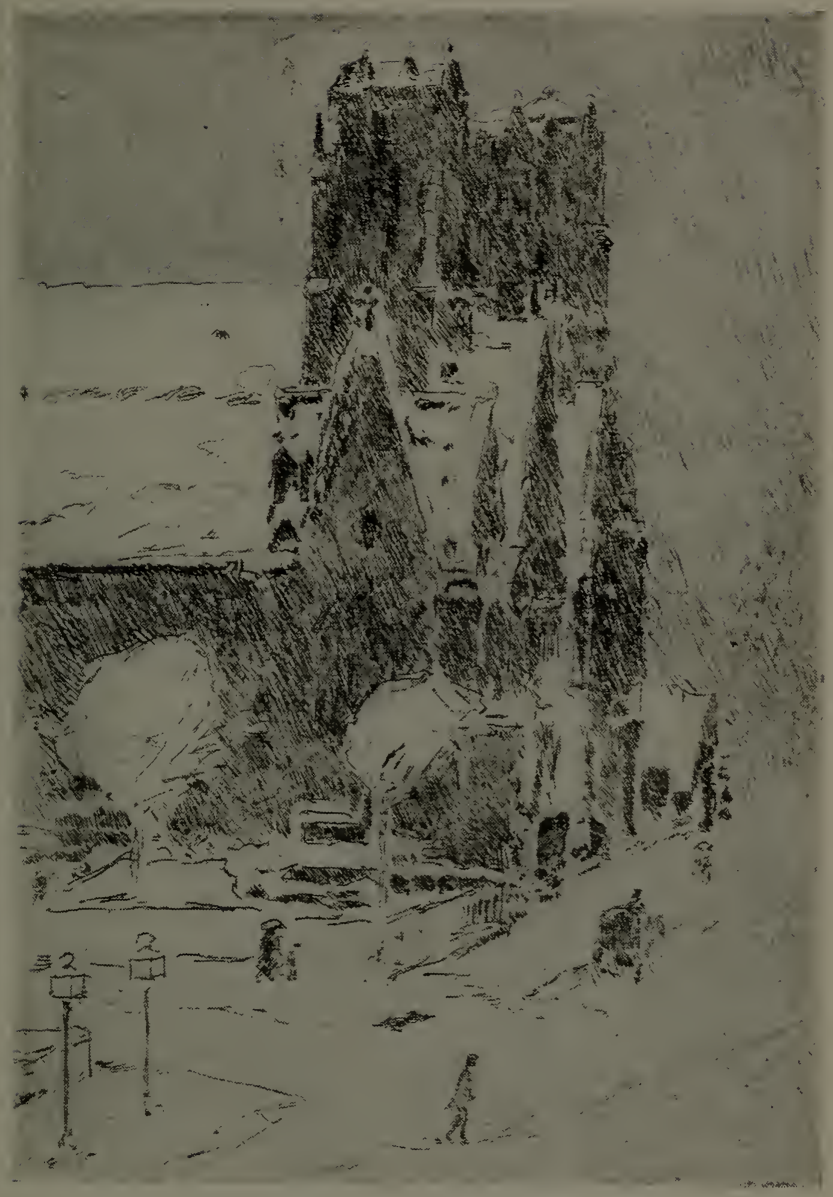

CALVARY CHURCH IN SNOW 

to vibrancy of atmosphere, to brilliance of sunlight, and its riotous interplay with shadow. This artist who has studied patiently and long the jostle of sunlight upon objects, the ever shifting luminous streamers that dart about upon the surface of things, who has searched out cunningly the delicate semi-tints and values, half sensed, half seen, that are revealed on the naked flesh in the open, who has discovered sumptuous patternings of leaf-accents and shadow-forms, has brought to this new medium the entire resource and accumulation of his knowledge, the skill and dexterity of his hand. It has been a renewal for him, a fresh out-. let and summing up of latent powers.

Childe Hassam may be interested in working out the same general problems of impressionism that he does in painting, but he approaches them from a different angle, along the linear path, giving us thereby much that is new and pleasant to see. Impressionist etchers are rare: there were Pissaro and Cezanne in his few plates, and perhaps Liebermann, Besnard, and Zorn. But as a general rule the impressionists confined their research to the domain of pigment and color. Thus it is all the more 
refreshing to come upon an impressionist who can also express his vision in terms of the etched line. Nor is he limited in his choice of subject. If one wishes the sparkle and animation of sunshine one may look at Toby's, or Cos Cob, or A Portsmouth Doorway; if one wishes the reticence and the magic atmosphere of beautiful interiors one may pick up The White Kimono or Reading in Bed (a plate that Rembrandt might have looked at more than once). What poetic charm there is in the conception of The Dutch Door, the girl standing at the door and drinking in with her fresh young nature the radiant summer that is jubilantly singing and caroling out of doors.

Childe Hassam has responded with rare grace to the charm of the Colonial. Many of his etchings are brief transcriptions of its sense and spirit into a more modern key. Not that he consciously seeks to reproduce the Colonial in art because it is old or American or fashionable, but he reacts to its intrinsic beauty and charm. Perhaps it was his birth and education in the heart of New England that gave him this sympathetic approach to the spirit of its past. The Portsmouth series of etchings, what 


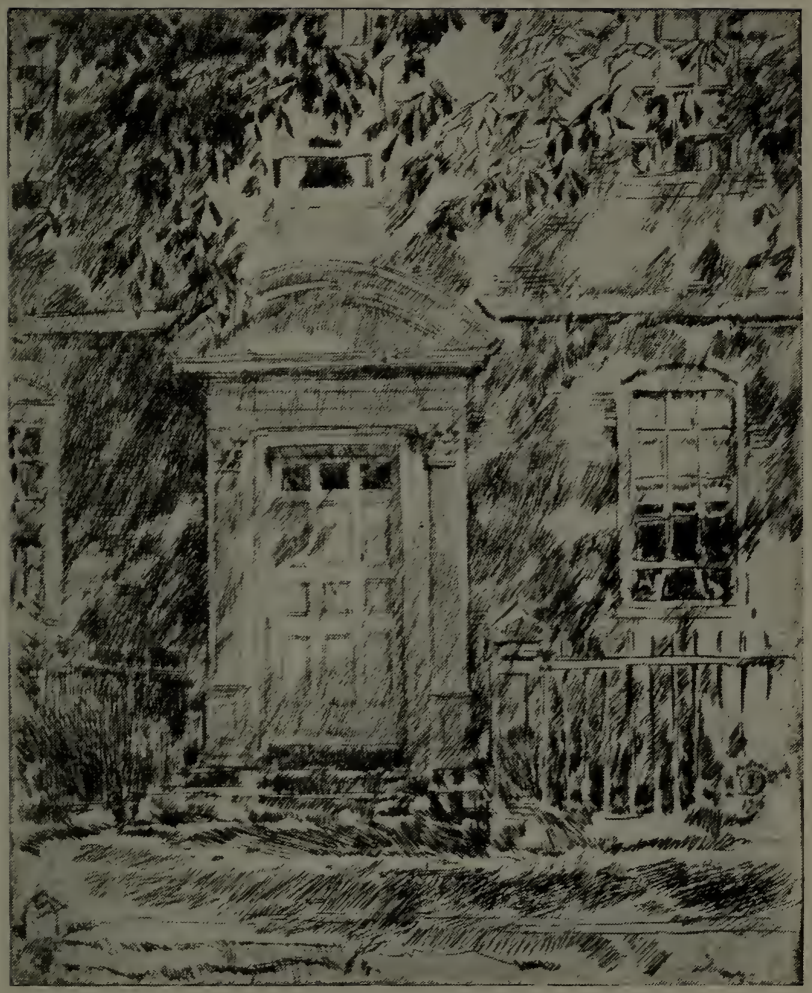

PORTSMOUTH DOORWAY 



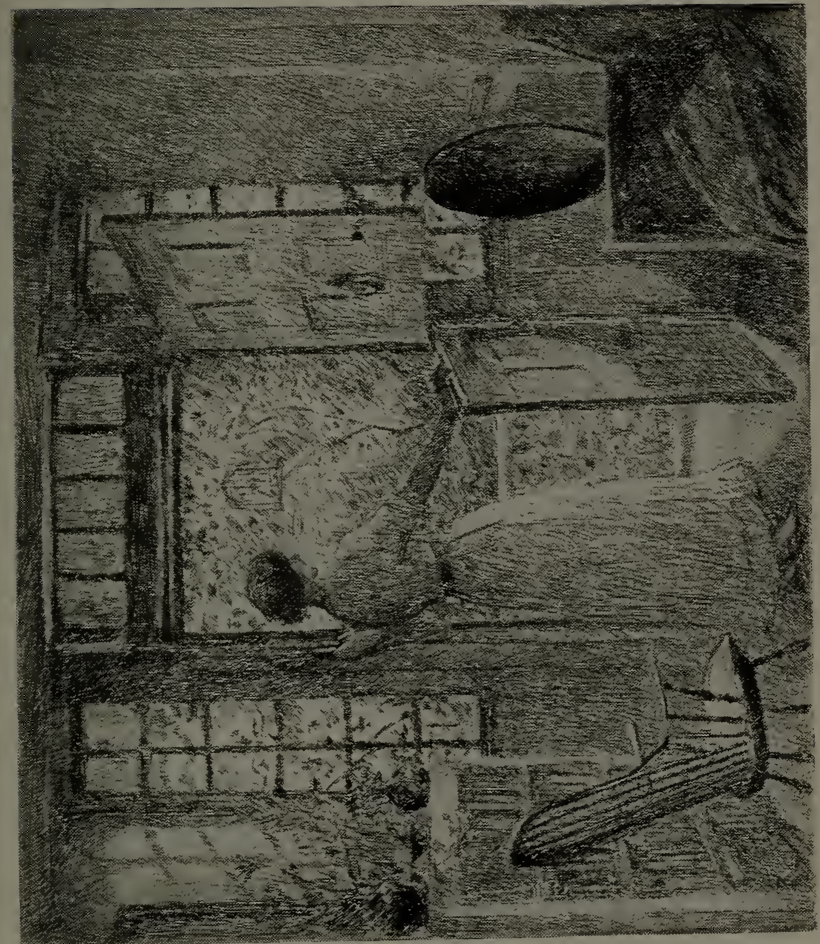

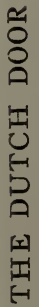



are they but glimpses and odd bits of old Colonial architecture, The Custom House, The Athenceum, and so on? And many of the Cos Cob prints are etchings in praise of a particularly fine old house-The Holley House, the residence of a fellow artist. He has sketched it lovingly both within and without-nay, he has celebrated almost every one of its rooms. I need mention but a few of the titles to suggest its potent charm. The White Kimono and The White Mantel give us a glimpse of two of its beautiful open fireplaces; The Dutch Door, The Writing Desk and The Steps give us picturesque aspects of its windows and doors. Childe Hassam is peculiarly happy in these arrangements of real and still life, compositions that breathe the very spirit of decoration.

That huge metropolis, Greater New York, has also excited his artistic interest. Through his eyes and under his hand New York assumes an almost unearthly glamour, a magic, fairy-like atmosphere. He sees it resplendent with flags in festive array or decked in the bright snowy blanket of winter. There is a little etching which he made last winter from his studio window, entitled 
The Church across the Way, that makes one pinch one's self to see whether one really is in this prosaic work-a-day city of New York - so fresh and charming is its vision, so much in the spirit of the wonder-cities of Europe. The old churches attract him; he sees St. Mark's on the Bouwerie through the mist and rain, and Old Calvary Church through the veil of the soft, clinging snowflakes. He watches the ceaseless procession of people on Fifth Avenue bustling or sauntering, riding or walking in the glare of the noonday sun. Childe Hassam says he is strongly tempted to execute a series of etchings from this same vantage-point at varying hours and seasons. Let us hope that he will do so, for he excels in the suggestion of atmosphere, of sun, snow, and rain.

Beside the etchings treating more specifically of towns and cities, Childe Hassam has made some very charming landscapes. There are three, for example, Cos Cob, The Old Toll Bridge, and Palmer's Dock - so nearly alike in size and intention as to warrant one in joining them together as a set-which strike a new note in American landscape etching. And then there are Elms 


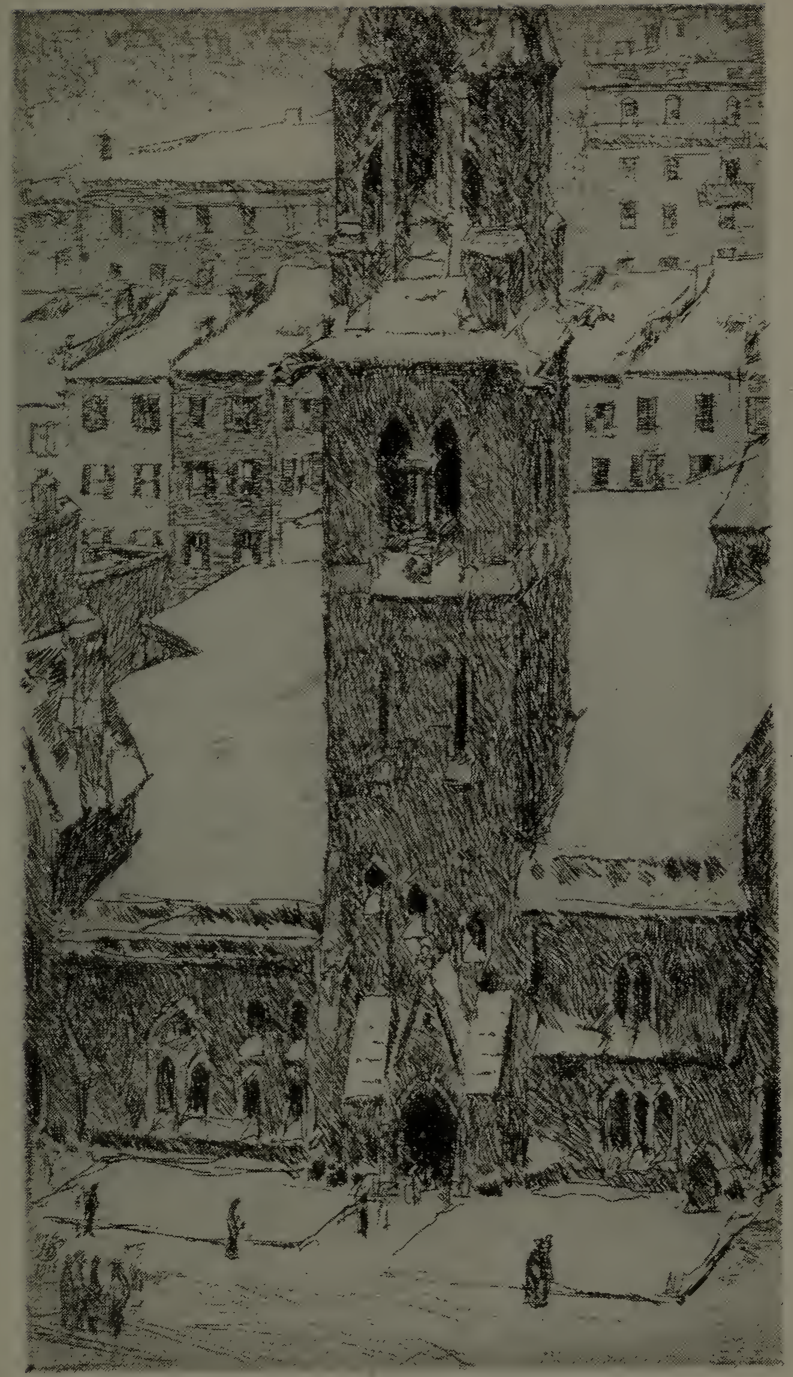

THE CHURCH ACROSS THE WAY 



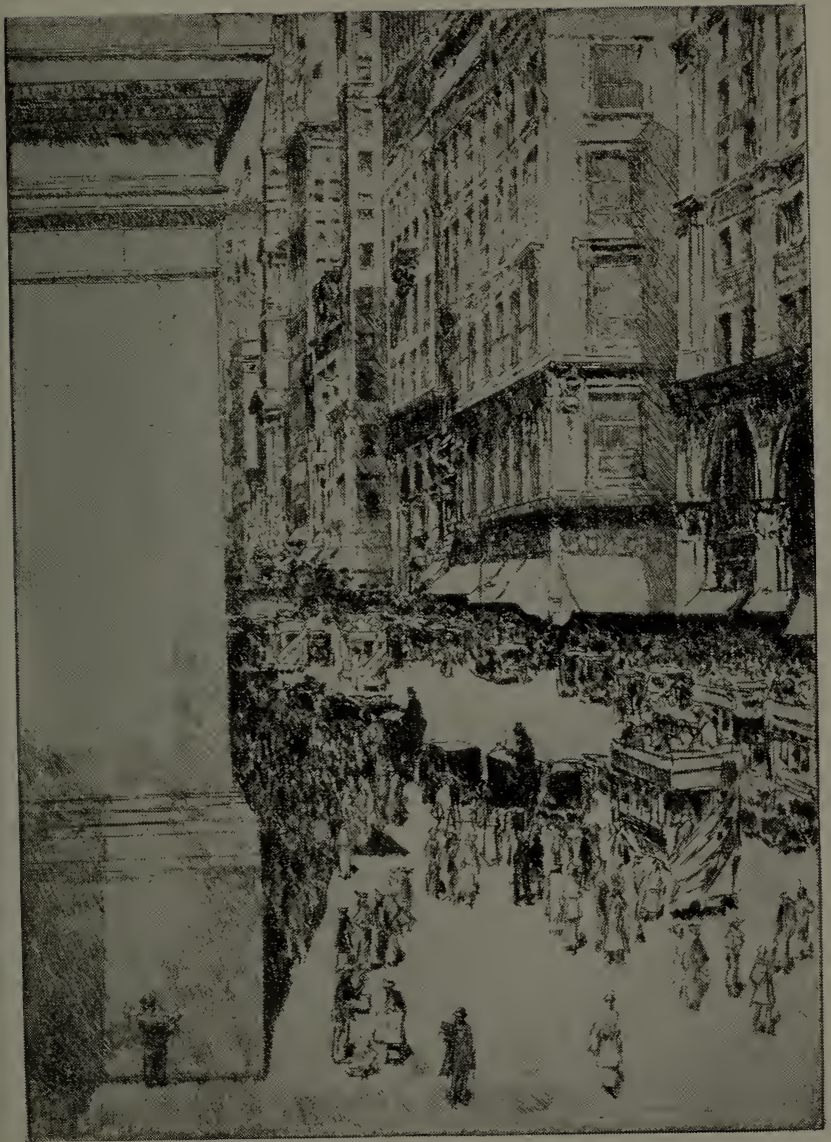

FIFTH AVENUE, NOON 



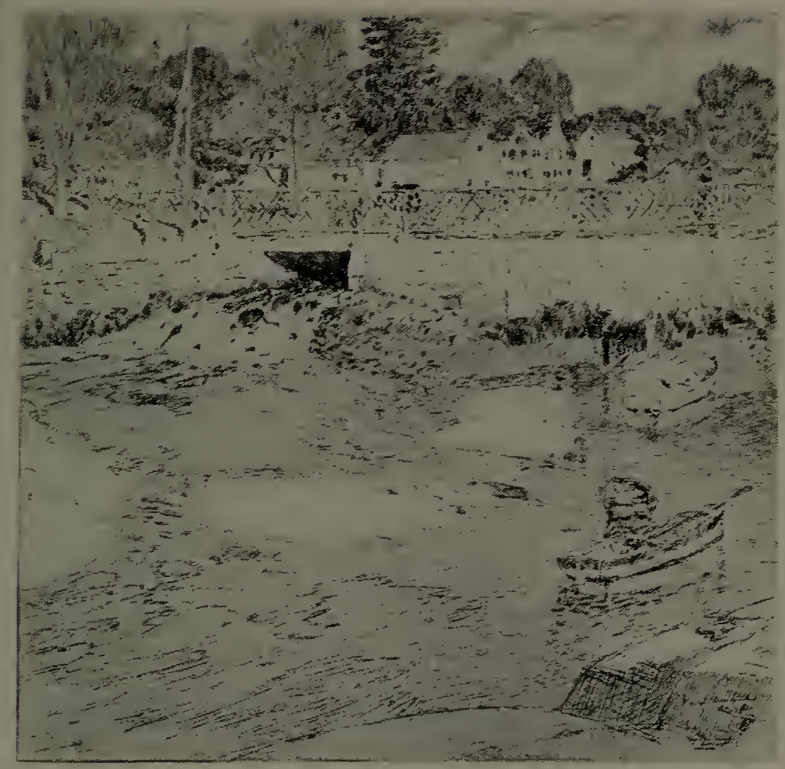

OLD LACE

in May, a delightful portrait of an old landmark at Yarmouth, Maine, and Old Lace, a view of the bridge and Cos Cob inlet at low tide. The delicate pattern and tracery of the design in the latter suggested to the artist the title, Old Lace. The High Pool and Diana's Pool bring up visions of joyous sunny days by rocky shores and inlets on the coast of Maine. From the pure landscapes the transition is easy to the imaginative or idealized landscapes, such as 
The Far Horizon or The Almond Tree, both of them most graceful and charming in design. Halcyon Hill, with its serenity and expansiveness, is conceived in the spirit of Walt Whitman's poem:

"As softness, fullness, rest suffuse the frame, like fresher, balmier air, As the days take on a mellower light, Then for the teeming, quietest, happiest days of all,

The brooding and blissful halcyon days."

If one examines his etchings with an eye for technical accomplishment, one may discover the origin and germinal idea of several distinct styles. Such a plate as Newfields, $N$. H., for example, seems to presage a new departure in the direction of exuberant atmospheric landscape arrangement. It is a vivid, breezy, riotous impression of earth and sky, the feeling of a day that makes one glad to be alive. In contrast to this are Street in Newburgh and Moonrise at Sunset, remarkable for their crispness and brevity, their intuitive yet energetic selection. The Street in Newburgh in particular impresses one with its vivid realization of form; the hill, the tree, the houses, 


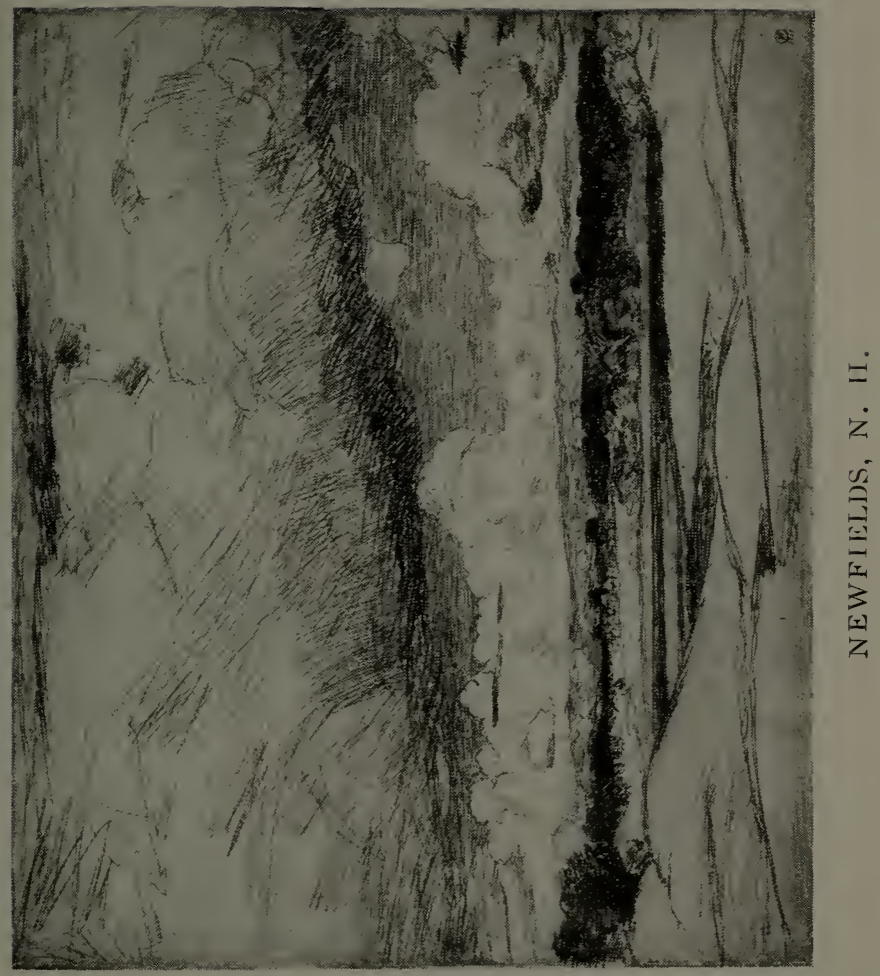





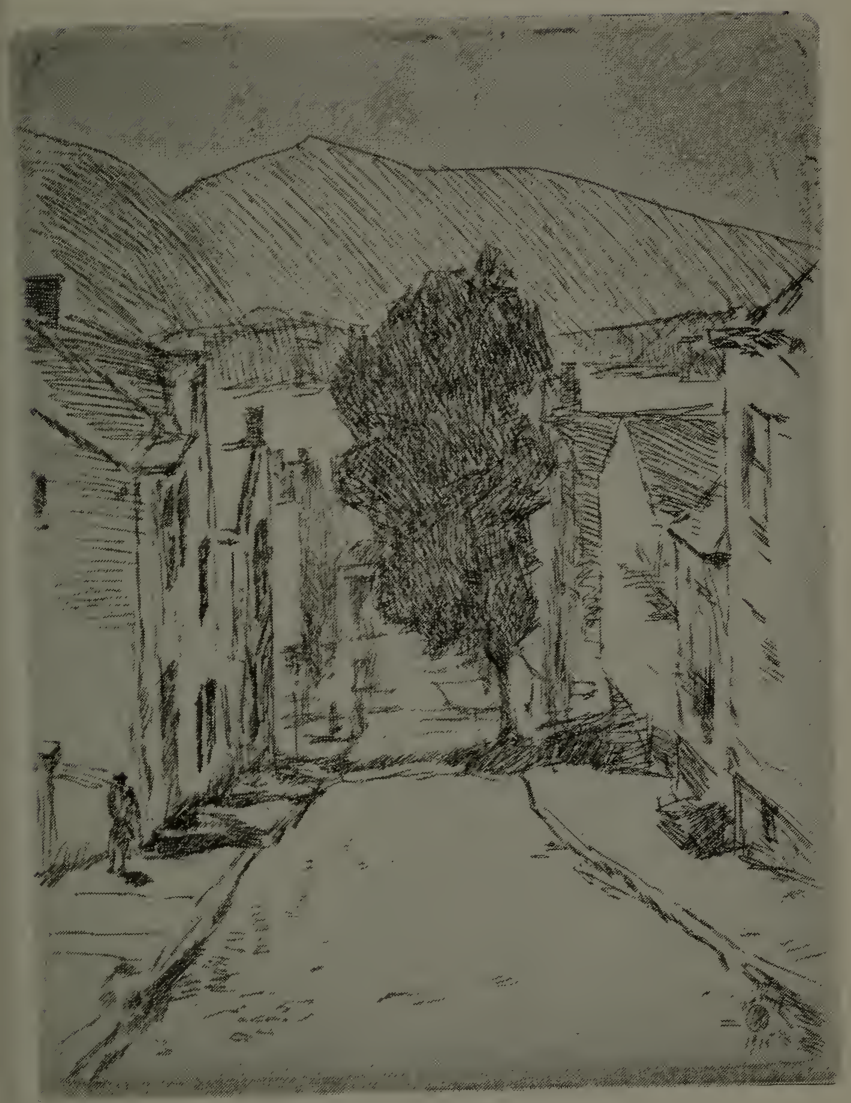

STREET IN NEWBURGH 

are reproduced in quintessence, the instantaneous precipitation of a mind surcharged with artistic energy. His most usual style -best exemplified in plates like Cos Cob or The Little Piano-is a translation, as it were, of the principles of impressionism into etching, the use of short lines, sometimes staccato, sometimes mellow, close together to suggest atmosphere and sparkling brilliance. It is a method effective in his hands, both in and out of doors, for the vibration of sunlight, the softness of shadows, and the vividness of inanimate objects. In his preparation for the actual etching process he adheres to no formula; at times he works from a finished drawing, at times directly from nature, at times again with a hasty sketch merely to place the composition. Like Jean François Millet, Childe Hassam does not hesitate to repeat his themes in various mediums; he sees no reason why an artist may not execute a painting, a water-color and an etching, all of the same subject, with only such variations as are consonant with complete and distinctive artistic expression.

Childe Hassam in his production confides in his public; he publishes whatever comes from his hand, the merest sketch as well as 
the completely executed etching. $\mathrm{He}$ is frank and confident in his own worth, he leaves it to Father Time to sift the wheat from the chaff. Chaff there must be wherever there is good grain. It is enough for him that he produce; he believes that even his failures will have interest for some. It is in this spirit that he gave to the world, during the two years that he has been etching, even those plates in which he first tried his hand in the technique of the art.

To him who is interested in discovering artistic kinships and tracing family trees (futile task generally), one would say that Childe Hassam and Whistler have much in common. There is the same untiring pursuit of the beauty of the world, the same preference for the decorative over the human element in picture craft, the same broad culture, and the same genius of creative taste. Especially are they united in the worship of a common goddess. For Childe Hassam also consecrates his choicest gifts to that "goddess of dainty thoughtreticent of habit, abjuring all obtrusiveness, purposing in no way to better others, . . seeking and finding the beautiful in all conditions and in all times." 


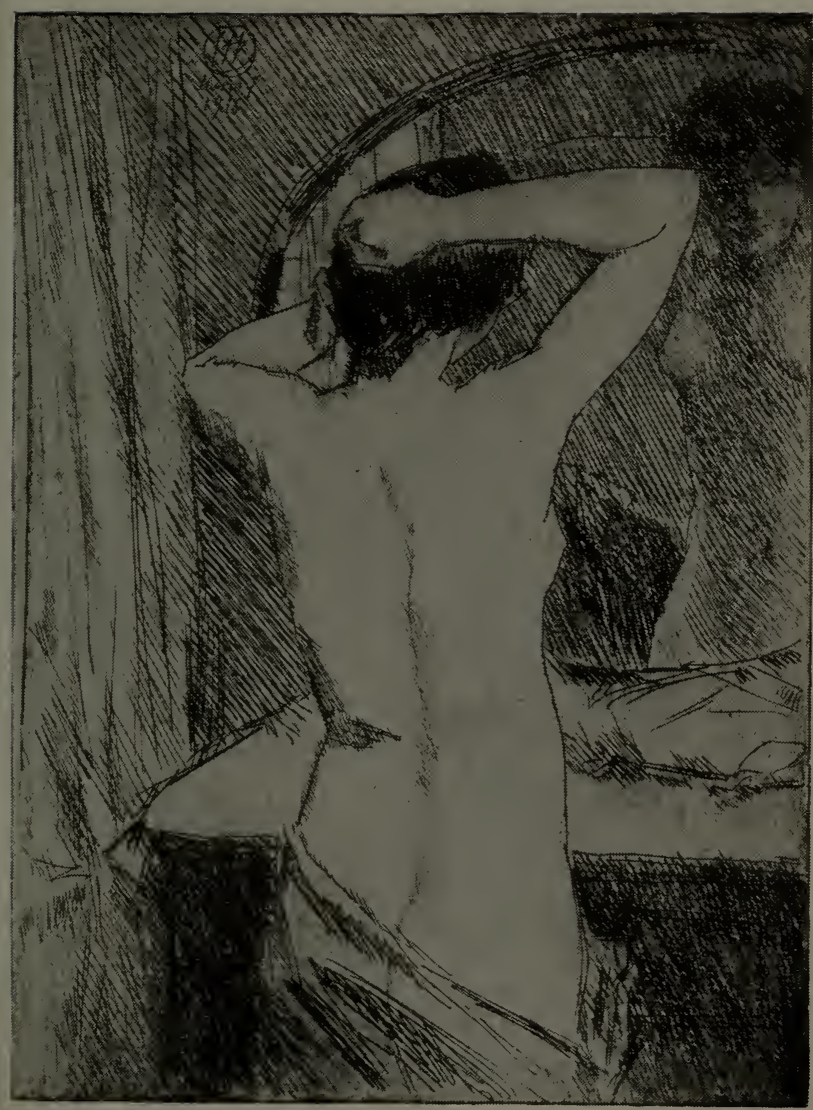

THE DRESSING TABLE 



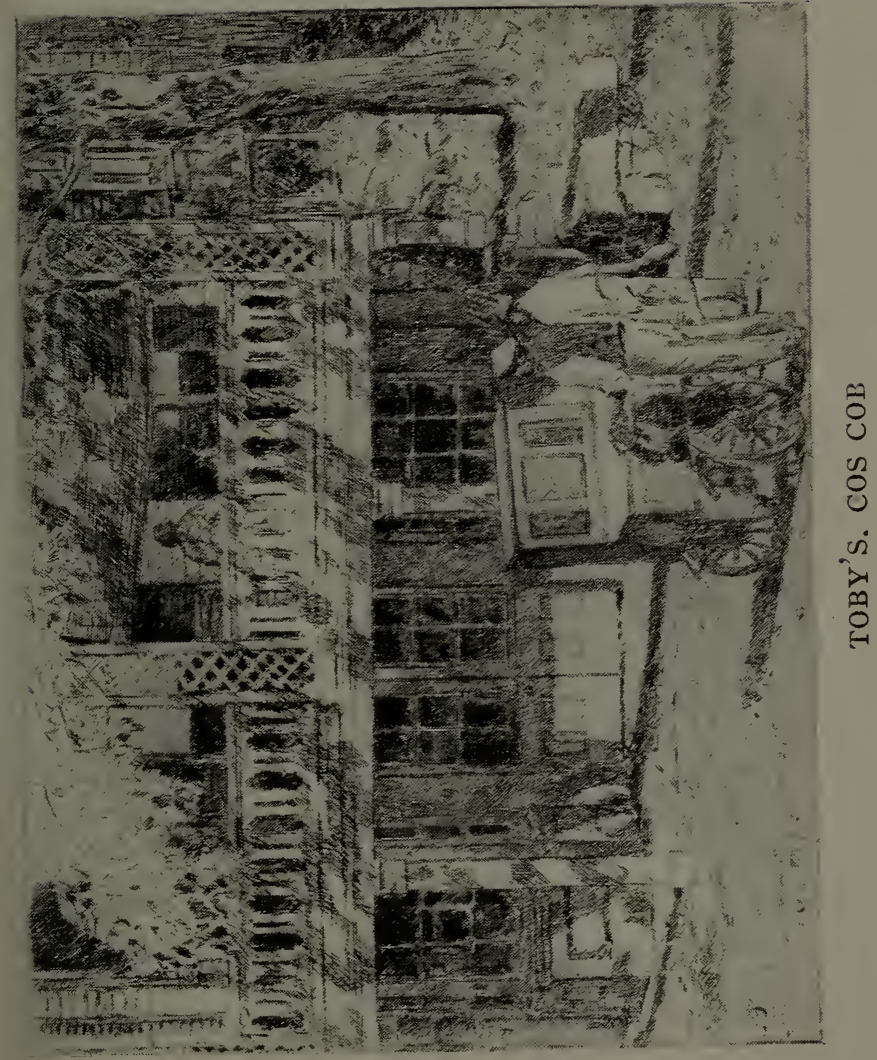





\title{
Childe Hassam
}

\section{A Catalogue \\ of his Etched Work}

\author{
By \\ Carl Zigrosser
}

December

$$
\text { I9I6 }
$$





\section{CA T A L O G E}

I Porte St. Martin

$$
\text { II } \times 7^{T} / 2 \text { inches. }
$$

Signed: C. H. 1898 near right margin.

Begun in 1898 , taken up and finished in $19 \mathrm{r} 5$.

2 Garden of the Luxembourg

$$
\text { I } \times 9 \text { inches. }
$$

Signed: C. H. 1898 in foliage upper left corner.

Begun in 1898 , taken up and finished in 1915 .

\section{Lannion}

Unsigned.

$$
4 \times 5 \text { inches. }
$$

Childe Hassam's first attempt at etching in I 9i5. Two proofs only, as plate was accidentally destroyed.

4 St. Sepulchre, Strand

$$
7 \times 47 / 8 \text { inches. }
$$

Signed: C. H. I9I5 in sky upper left corner.

Done from a drawing.

Eleven proofs only, as plate was accidentally destroyed.

\section{The Laurel Wreath}

$$
9^{1 / 8} \times 47 / 8 \text { inches. }
$$

Signed: C. H. 1907 in lower left corner.

Done from a drawing executed in 1907 .

\section{The Lilies}

$$
67 / 8 \times 53 / 8 \text { inches. }
$$

Signed: C. H. 1905 in lower right corner.

Done from a drawing executed in 1905 . 
7 The Little Pool, Appledore

$5 \mathrm{r} / 2 \times 3$ inches.

Signed: C. H. IOI 5 in lower right corner.

Done from drawings made at the Isles of Shoals.

8 At the Opera

$5 \frac{1}{2} \times 4$ inches.

Signed: C. H. I9I5 near right margin.

Done from a drawing made one evening in a box at the opera.

9 Contre-Jour

$7 \times 5 \mathrm{~T} / 2$ inches.

Signed: C. H. I9I5 in lower left corner.

Done from model.

ro West Point

$3^{T / 2} \times 57 / 8$ inches.

Signed : C. H. I9I5 in sky.

Done from nature in June, I9I5.

I I Street in Newburgh.

$6 \times 4^{1 / 2}$ inches.

Signed: June, Newburgh, C. H. I9I5 lower right corner.

Done from nature in June, I9I5.

I2 Long Beach

$5^{\mathrm{T} / 2} \times 6^{\mathrm{T}} / 2$ inches.

Signed: C. H. June, I9I5 in lower right corner.

Done from nature in June, I9I5.

I3. Old Warehouses, Portsmouth

$51 / 2 \times 67 / 8$ inches.

Signed: Portsmouth, C. H. Aug. 30, I9I5 lower left corner.

Done from nature.

I4 The Athenæum, Portsmouth

$8 \mathrm{I} / 4 \times 57 / 8$ inches.

Signed: Portsmouth, C. H. I9I5 with "Dot" in lower left corner.

Done from nature in Miss Dorothy Whitcomb's car. 
I5 The Old Custom House, Portsmouth

$$
53 / 8 \times 63 / 4 \text { inches. }
$$

Signed: Portsmouth, C. H. I9I5 in upper left corner.

Done from nature in August, I915.

\section{I6 The Chimneys, Portsmouth}

$$
57 / 8 \times 8 \text { inches. }
$$

Signed: Portsmouth, C. H. I9I5 in lower left corner.

Done from nature in August, 19I 5.

\section{I7 The Ox Cart}

$43 / 4 \times 7$ inches.

Signed: C. H. IOI5 in upper left corner.

Done from a drawing executed at Old Lyme.

\section{I8 Sunset, Constable's Hook}

$$
5 \times 67 / 8 \text { inches. }
$$

Signed: C. H. IOI5 in lower right corner.

Done from a point drawing.

\section{I9 Madison Square}

$$
4 \times 5 \mathrm{~T} / 2 \text { inches. }
$$

Signed : C. H. $I 892$ in upper left corner.

Done from a drawing executed in New York in 1892 .

20 Rainy Day, St. Mark's

$$
7 \times 4^{1 / 2} \text { inches. }
$$

Signed : C. H. I9I5 in lower right corner.

Done from a point drawing.

\section{I The Dance}

$$
\text { II } \times 7 \mathrm{I} / 2 \text { inches. }
$$

Signed : C. H. I9I5 in lower right corner.

Done from a drawing.

First State, before several of the figures to left and right were removed and further work added. About six proofs printed.

Second State, with the changes mentioned above. About ten proofs printed. 
Third State, with further work on spot to left where the woman holding the mirror had been. The figure to the right, partly covered over with additional work in the second state, now emerges with face rendered visible, and with uplifted hand and scarf in gesture of waving.

\section{The Laurel Dance}

$$
7 \times 7 \text { inches. }
$$

Signed: C. H. I9I5 in foliage near lower right margin.

Done from notes taken at a festival at Mount Kisco, June, I9I 5 .

\section{Kitty Resting}

$$
4 \times 5 \frac{\mathrm{T}}{2} \text { inches. }
$$

Signed: C. H. IOI5 near upper margin.

Done from life in the studio.

\section{Moonrise at Sunset}

$$
43 / 4 \times 67 / 8 \text { inches. }
$$

Signed: C. $H$. near lower margin.

Done from a point drawing.

25 June

$$
5 \frac{1}{2} \times 3 \text { inches. }
$$

Signed: C. H. I9 I 5 in lower right corner.

Done from a study for the painting of the same name.

26 Nude-Hamadryad

$$
61 / 2 \times 4 \frac{1}{2} \text { inches. }
$$

Signed: C. H. I9I5 in upper right corner.

Done from life.

27 The Etcher

$$
7 \times 47 / 8 \text { inches. }
$$

Signed: Cos Cob, C. H. I9I5 near lower margin.

Done from nature.

Childe Hassam in Harold Eby's studio at Cos Cob. 


\section{Reading in Bed}

$67 / 8 \times 5 \frac{1 / 2}{1}$ inches.

Signed: $C . H$. in lower left corner.

Done at his New York apartment from life in a half hour sitting.

A portrait of Mrs. Hassam.

\section{The Georgian Chair}

\section{$5 \times 4$ inclies.}

Signed: C. H. I9I5 through open window.

Done from life at Exeter, N. H.

A portrait of Miss Dorothy Whitcomb.

\section{The Little Piano}

\section{$5 \times 4$ inches.}

Signed: C. H. I9I5 on music book.

Done from life in an impromptu sitting at New York.

There are slight variations in the proofs due to additional work too vague to mention.

\section{I The Illustrator}

$$
7 \times 97 / 8 \text { inches. }
$$

Signed: Cos Cob, C. H. I9I5 in lower right corner.

Done from life in one short sitting.

A portrait of Harold Eby in his studio at Cos Cob.

First State, before the nose and contour of the neck were slightly rubbed down. About eight proofs printed.

Second State, with the changes mentioned above.

\section{$32 \mathrm{Cos} \mathrm{Cob}$}

$$
67 / 8 \times 5 \text { inches. }
$$

Signed: $\operatorname{Cos} C o b, C . H .19 I 5$ in water lower right margin.

Done from nature.

A view of Harold Eby's studio by the waterside. 


\section{The Old Toll Bridge}

$67 / 8 \times 53 / 8$ inches.

Signed: C. H. I9I5 in lower left corner.

Done from nature at Stratham, N. H.

\section{Palmer's Dock, Cos Cob}

$77 / 8 \times 5 \frac{1}{2}$ inches.

Signed: Cos Cob, C. H. I9I5 near left margin.

Done from nature.

First State, before the shadows underneath the dock were lightened. About five proofs printed.

Second State, with the changes mentioned above.

\section{The Barges}

$$
5 \times 7 \frac{1}{2} \text { inches. }
$$

Signed: Cos Cob, C. H. in upper right corner.

Done from nature at Cos Cob.

36 The Breakfast Room

$$
\text { II } \times 7 \frac{1}{2} \text { inches. }
$$

Signed : C. H. June, I9I5, near right margin.

Done from nature at the Holley House, Cos Cob.

37 Painting Fans

$67 / 8 \times$ Ir inches.

Signed: C. H. I9I5 in lower right corner.

Done from nature at the Holley House, Cos Cob.

38 Connecticut Barns

$$
7 \times 93 / 8 \text { inches. }
$$

Signed: Cos Cob, C. H. I9I5, Sept. 27, on barn to left.

Done from nature.

The Brush barns at Cos Cob.

39 The Old House

$$
61 / 2 \times 73 / 4 \text { inches. }
$$

Signed: Cos Cob, C. H. I9I5 in lower right corner. 
The old Holley House reconstructed as it was one hundred years ago.

Underbitten. Plate destroyed. About fifteen proofs printed.

40 An Old House, Connecticut

$6 \pm / 2 \times 73 / 4$ inches.

Signed: Cos Cob, C. H. I9I5 in lower right corner.

Done from nature.

The Brush house by the waterside, Cos Cob.

\section{I Moonlight-The Old House

$$
73 / 8 \times 93 / 4 \text { inches. }
$$

Unsigned.

Done from nature.

Overbitten. Plate destroyed. About four or five proofs printed.

42 Long Ridge

$73 / 8 \times 87 / 8$ inches.

Signed: Sept. 28, Long Ridge, C. H. I9I5. near lower margin.

Done from nature in company with Harold Eby about fourteen miles inland from Cos Cob.

43 Elms in May

$$
63 / 4 \times 107 / 8 \text { inches. }
$$

Signed: Yarmouth, C. H. I9og in lower right corner.

Done in October, I9I5, from a drawing executed at Yarmouth in 1909 .

The Whitcomb Elms at Yarmouth, Maine.

\section{The Old Cherry Tree}

$$
7 \pi / 2 \times 97 / 8 \text { inches. }
$$

Signed : C. H. lower left corner.

Done from nature.

The arbor and lane back of the Holley House at Cos Cob. 
45 Low Tide, Cos Cob Bridge $73 / 4 \times 107 / 8$ inches.

Signed: Cos Cob, C. H. IOI5 in upper left corner.

Done from nature in October, I9I 5.

First State, before the river bed was darkened and the pile of stone in front corered with light lines. About fifteen proofs printed.

Second State, with changes mentioned above; additions in January, 1916.

46 The Lucinda of New York

$63 / 4 \times 67 / 8$ inches.

Signed: Cos Cob,C. H., 1915 under roof of house.

Done from nature at Cos Cob.

47 The Bird Book

I $0 \times 8 \mathrm{I} / 2$ inches.

Signed: C. H. I9I.5 near left margin.

Done from nature at Cos Cob.

First State, before the figure of the girl was replaced by flowers and still life. Three proofs printed.

Second Statc, with the changes mentioned above.

Childe Hassam started to rub down the waist of the figure and the plate went to pieces, so he put in the vase and flowers and strengthened the plate generally.

\section{The Dutch Door}

$83 / 8 \times 97 / 8$ inches.

Signed: C. H. I9 I5 left margin near flowers in jar.

Done from nature.

One of the doors of the Holley House at Cos Cob. The model was Miss Helen Burke, daughter of Toby Burke. 
49 The White Kimono

$$
73 / 8 \times 107 / 8 \text { inches. }
$$

Signed: C. H. I9I5 near right margin.

Done from nature.

A fireplace in the Holley House at Cos Cob. The model was Miss Helen Burke.

50 The White Mantel

$67 / 8 \times 97 / 8$ inches.

Unsigned.

Done from nature.

The fireplace in the dining-room of the Holley House at Cos Cob. The model was Miss Helen Burke.

\section{I The Colonial Table}

$$
67 / 8 \times 97 / 8 \text { inches. }
$$

Signed: C. H. I9I5 in upper left corner.

Done from nature.

A scene at the Holley House, Cos Cob.

52 The Steps

I0 $1 / 2 \times 7 \mathrm{~T} / 2$ inches.

Signed: Sept. 19, 1915, Cos Cob, C. H. near right margin.

Done from nature.

A portrait of Mrs. Elmer Livingston MacRae on the steps of the Holley House at Cos Cob.

53 The Writing Desk

$$
\text { Io } \times 7 \text { inches. }
$$

Signed: $\operatorname{Cos} \mathrm{Cob}$, C. H., I9I5 upper right corner.

Done from nature.

A portrait of Mrs. Hassam at the Holley House. Mr. Hassam considers it a very good likeness, especially the profile.

\section{The Old House, Cos Cob}

$$
63 / 8 \times 83 / 8 \text { inches. }
$$

Signed: Cos Cob, C. H. Oct. 27, I9I5 in lower right corner. 
Done from nature.

A view of the Holley House at Cos Cob.

\section{Toby's, Cos Cob}

$$
67 / 8 \times 87 / 8 \text { inches. }
$$

Signed: Cos Cob, C. H. I915, Oct. 31 in lower left corner.

Done from nature.

Toby Burke's public house at Cos Cob.

56 Old Lace

$7 \times 7$ inches.

Signed: Cos Cob, C. H. I9I5 in lower right corner.

Done from nature, October, I9I5.

$A$ riew of the bridge and Cos Cob inlet at low tide. The delicate pattern and tracery of the design suggested to Mr. Hassam the title, Old Lace.

\section{Cos Cob Dock}

$$
83 / 8 \times 6 \mathrm{I} / 4 \text { inches. }
$$

Signed: Cos Cob, C. H. I9I5 near left margin.

Done from nature in November, I9r 5.

Another view of Harold Eby's studio by the waterside.

\section{Old Dutch Church, Fishkill Village}

$$
73 / 8 \times 103 / 8 \text { inches. }
$$

Signed: Fishkill, June 4, C. H. IOI5 in lower right corner.

Done in November, after a drawing executed at Fishkill early in June.

Harvey Birch, the hero of James Fenimore Cooper's novel "The Spy," is supposed to have sought refuge in this church.

First State, before the bare spaces in lower clumps of foliage were covered with cross lines and other bare spaces on the trunks covered with fine lines. About eight proofs printed.

Second State, with changes mentioned above. 
59 Portrait

$$
5^{1 / 2} \times 43 / 8 \text { inches. }
$$

Signed: C. H. New York, 1915 near left margin.

Done from life in November, I9I5.

First State, before fine dry-point lines were added on neck, breast and face. About fifteen proofs printed.

Second State, with the changes mentioned above. There are now no blank spots on the model's right cheek and the right side of the nose.

6o Mrs. R.

$$
\text { II } \times 7 \text { inches. }
$$

Signed: C. H. I9I5 in upper right corner.

Done from life one day in December, I915, in two short sittings broken into by lunch.

A portrait of Mrs. Hugo Reisinger.

\section{I Young Pan Piping}

$$
63 / 8 \times 7^{1 / 2} \text { inches. }
$$

Signed: Christmas, C. H. IOI5 in lower left corner.

Done from a pastel drawing in the possession of C. E. S. Wood.

\section{Calvary Church in Snow}

$$
7 \times 478 \text { inches. }
$$

Signed: Dec. 27, C. H. I9I5 in lower left margin.

Done from a drawing executed at New York in 1904 .

\section{The Three Little Girls}

$$
57 / 8 \times 3^{1 / 2} \text { inches. }
$$

Signed : C. H. 1916 in lower right margin.

Done in January, I916, from a drawing executed out-of-doors at Cos Cob the previous summer.

The young daughters of Cos Cob artists. 


\section{The Scarf Dance (Four Figures)}

$67 / 8 \times 67 / 8$ inches.

Signed: C. H. I9I6 in lower right margin.

Done in the studio in January, 1916, with posed models and with background made from notes taken at Mount Kisco.

65 The Butterfly Dance (One Figure)

$53 / 4 \times 33 / 8$ inches.

Signed: C. H. I9I6 in lower right margin.

Done in the studio January, I9I6, with posed models and with background made from notes taken at Mount Kisco.

\section{The Church Across the Way}

\section{$81 / 8 \times 43 / 8$ inches.}

Signed: Nerv York, C. H. I9I6 in lower left corner.

Done from nature from the studio window, in January, I9r6.

67 Battery Park

I $23 / 4 \times 7$ inches.

Signed: New York, C. H. Jan. I8, I9I6 in lower left corner.

Done from nature on the plate. The print therefore appears reversed.

First State, before the shadows on the planes of the building to the left and on the Singer Building were rubbed down. About ten proofs printed.

Second State, with the changes mentioned above. The cast shadow on the building directly below the Woolworth Building has been rubbed down and altered in shape, continuing the eye. still further down underneath the elevated train; there are now two light spots where there was only one before.

68 Washington's Birthday: Fifth Avenue and $23 d$ Street

I $23 / 4 \times 7$ inches. 
Signed: C. H. Nerv York, Feb. 22, 1916 on a flag near left margin.

Done practically from nature with the aid of hasty notes.

First State, before the cast shadow of the Metropolitan Tower was added on lower part of the Flatiron Building. About ten proofs printed.

Second State, with the changes mentioned above.

69 Manhattan

$5^{\mathrm{T}} / 2 \times 10$ inches.

Signed: C. H. Brooklyn in lower left corner. Done in February, I916, from a drawing executed in September, I9II.

A view of Manhattan from the Touraine on Brooklyn Heights.

70 The Roofs: South from 57 th Street $7 \times 53 / 8$ inches.

Signed: C. H. New York I9I6 in lower left corner.

Done from nature in March, I916, from his apartment window.

\section{I Church Doorway, Snow}

$7 \times 53 / 8$ inches.

Signed: C. H. New York 1916 in lower right corner.

Done from nature in March, 1916.

The doorway of the Calvary Baptist Church in 57 th Street.

\section{The Dressing Table}

\section{$5 \frac{1}{2} \times 4$ inches.}

Signed: March 7, C. H. 1916 near upper margin.

Done from life. 


\section{The Swimmer, Morning (facing water)} $9 \times 5 \frac{7 / 8}{8}$ inches.

Signed: C. H. I9I6 in upper left corner.

Done in March, I916, from posed model in studio, with background added from paintings made at the Isles of Shoals.

\section{The Swimmer, Evening (facing land)}

$$
9 \times 57 / 8 \text { inches. }
$$

Signed : C. H. I9I6 in lower right corner.

Done in March, I916, from posed model in studio, with background added from paintings made at the Isles of Shoals.

75 The Goddess

$$
9 \times 53 / 4 \text { inches. }
$$

Signed : C. H. 1916 on upper fold of drapery. Done in March, I916, from posed model in studio, with background added from paintings made at the Isles of Shoals.

\section{The Auto School}

$$
4 \times 7 / 8 \text { inches. }
$$

Signed: New York, C. H. I9I6 near right margin.

Done in March, igr6, from a drawing executed on Seventh Avenue in rigr.

\section{Fifth Avenue, Noon}

$$
97 / 8 \times 7^{1 / 2} \text { inches. }
$$

Signed : C. H. April I, I9I6 on base of building to left.

Done from nature from a window at Fifth Avenue and 34 th Street.

First State, before the plate was cut down on the left to $7 \frac{1}{4}$ inches, leaving the unbroken contour of the wall of the Altman Building. About twenty proofs printed. Second State, with the changes mentioned above. 


\section{The Waning Moon}

$2 \frac{1}{2} \times 2^{T / 2}$ inches.

Signed: May, C. H. I9I6 in lower left corner.

Done from a sketch made at the Isles of Shoals.

79 Nocturne: Cos Cob

Unsigned.

$3^{1 / 4} \times 4$ inches.

Done from a sketch at Cos Cob.

80 Winter, Central Park

$7 \times 7$ inches.

Signed: March I7, C. H. I9I6 near right margin.

Done from a drawing executed in March. I9 6.

\section{I Spring, Central Park}

$3^{1 / 2} \times 3 \frac{3 / 8}{}$ inches.

Signed: C. H. I9I6 in lower left corner.

Done from nature.

82 Rue de Nevers, Paris

$73 / 8 \times 3^{1 / 2}$ inches.

Signed : Paris, C. H. I9IO on farthest building.

Done from a drawing executed at Paris in I9 10.

83 Rue du Chat qui Pêche, Paris

$5 \times 37 \% 8$ inches.

Signed: C. H. I9IO on centre wall.

Done from a drawing executed at Paris in I 9 Io.

\section{Zola's House, Paris}

\section{$53 / 8 \times 4$ inches.}

Signed: Paris, C. H. I887 near lower left margin.

Done from a drawing executed at Paris in I 887 . 
85 Montmartre

$45 / 8 \times 6 \frac{1}{4}$ inches.

Signed: Paris, C. H. $I 887$ near left margin. Done from a drawing executed at Paris in I 887 .

86 Fish Shop, Jermyn Street, London

$31 / 2 \times 6$ inches.

Signed: London, C. H. I9IO in lower right corner.

Done from a drawing executed at London in I9I 0.

87 The Bill Boards, New York

$45 \% 8 \times 6 \frac{1}{4}$ inches.

Signed: New York, C. H. 1896 near lower margin.

Done from a drawing executed at New York in 1896 .

88 Old Shops, New York

$3 \frac{1}{2} \times 6$ inches.

Signed: New York, C. H. 1902 in lower left corner.

Done from a drawing executed at New York in 1902.

89 Union Square

$4 \frac{1}{4} \times 53 / 4$ inches.

Signed: Neru York C. H. 1896 near lower right margin.

Done from a drawing executed at New York in 1896 .

90 The Old Elm

$41 / 2 \times 63 / 8$ inches.

Signed: Old Lyme, C. H. I9o9 in lower left corner.

Done from a drawing executed at Old Lyme in 1909 . 


\section{I The Linden Tree}

$$
67 / 8 \times 478 \text { inches. }
$$

Signed: C. H. I9I6 in water.

Done from a drawing made at Old Lyme, similar to the decorative panel in Miss Florence Griswold's house at Old Lyme.

\section{The Greek Dance}

$$
81 / 4 \times \text { Io inches. }
$$

Signed : C. H. 1916 near left margin.

Done from posed models in studio with background from paintings made at the Isles of Shoals.

\section{Fresco}

$4^{1 / 2} \times 67 / 8$ inches.

Signed: C. H. I9I6 near lower right margin. Done from a pen drawing made as a study for a panel in the Library of C. E. S. Wood, Portland, Oregon.

\section{Toledo}

$$
6 \mathrm{~T} / 8 \times 95 / 8 \text { inches. }
$$

Signed: Toledo, C. H. I9IO on wall, upper right corner.

Done from a water-color drawing executed at Toledo in r 910.

\section{Old Chinatown, San Francisco \\ $5 \frac{1}{4} \times 5$ inches.}

Signed: C. H. Igot near right margin.

Done from a drawing executed at San Francisco in I904.

A bit of old Chinatown before the earthquake.

\section{The Summer Sofa}

\section{$71 / 2 \times 5 \frac{1}{2}$ inches.}

Signed: June IO, C. H. I9I6 in upper right corner.

Done from a model at the studio, New York. 
97 The Far Horizon

I $07 / 8 \times 83 / 8$ inches.

Signed : C. H. I9I6 in lower right corner.

Done out-of-doors with a posed model.

Symbolic of the forward vision-the hope of a better future for the world.

98 Diana's Pool, Appledore I0 $7 / 8 \times 73 / 8$ inches.

Signed : C. H. I9I6 in lower right corner. Done from nature on the coast of Maine.

99 The High Pool

$4 \frac{1}{2} \times 3$ inches.

Signed: C. H. I9I6 near right margin.

Done from a drawing.

Ioo Madonna of the North End

$6 \mathrm{~T} / 2 \times 4^{\mathrm{T}} / 2$ inches.

Signed: C. H. I9I6 upper left corner.

Done from drawings made at Boston in August, I9I4.

Iо I Portsmouth, Evening

$27 / 8 \times 43 / 8$ inches.

Signed: Portsmouth, C. H. I9I6 near lower left margin.

Done from nature in August, I9r6.

102 Portsmouth Doorway

$5 \mathrm{~T} / 2 \times 4^{\mathrm{T} / 2}$ inches.

Signed: Portsmouth, C. H. I9I6 near lower right margin.

Done from nature in August, 1916.

A doorway of the Warner House at Portsmouth.

I03 Fire Dance

$6 \mathrm{~T} / 2 \times 4$ inches.

Signed: August 28, C. H. 1916 in lower left margin.

Done from life at Portsmouth, in August. I9I 6. 


\section{I04 Dance in the Garden (Two Figures)}

$51 / 2 \times 4^{1} / 2$ inches.

Signed: August 23, Portsmouth, C. H. I9I6 in lower left corner.

Done from life.

\section{I05 Newport Harbor}

$67 / 8 \times 61 / 4$ inches.

Signed: C. H. I9I6 in sky.

Done from nature in August, I9I6.

\section{I06 Newfields, N. H.}

\section{$93 / 8 \times$ I I $3 / 8$ inches.}

Signed : C. H. I9I6 in lower right corner.

Done from nature in September, I9I6, at the

Whitcomb Farm, New Hampshire.

\section{I07 Halcyon Hill}

\section{$87 / 8 \times$ II $1 / 4$ inches.}

Signed : C. H. I9I6 near lower left margin.

Done after studies for a painting of the same name, in September, I9r6.

First State, before left cloud was slightly reduced and before additional work in the reflections of the water to the left. About four or five proofs printed.

Second State, with the changes mentioned above. There are now no large blank spaces in the water.

\section{I08 The Surf}

\section{$63 / 8 \times 43 / 8$ inches.}

Signed : C. H. I9I6 in upper right corner.

Done about September i 5 th, from a drawing.

\section{Io9 Albert Roullier}

$$
6 \times 4 \text { inches. }
$$

Signed: Chicago, C. H. Oct. 29th, I9I6 in upper left margin.

Done from life at a half-hour sitting.

A portrait of the print seller, Albert Roullier, seated in his print cabinet. 


\section{Io The Little Model Resting}

$$
5 \times 5 \text { inclies. }
$$

Signed: Nea York, C. H. I9I6 in upper left corner.

Done from life in the studio, November, I 9 I 6.

\section{I I Stock Broker's Office, Wall Street}

$$
4 \times 53 / 4 \text { inclies. }
$$

Signed: New York, C. H. Nor'. 8, 1916 in lower right corner.

Done from nature.

\section{2 The Almond Tree}

$$
\text { I I } \times 5 \frac{3 / 4}{4} \text { inches. }
$$

Signed: C. H. I9I6 in lower left corner.

Done from posed model and from the painting of the same name at the studio, Novemiber I I, I 9 I 6 .

\section{3 John Burroughs}

$$
5 \times 4 \frac{1}{2} \text { inches. }
$$

Signed: Nea York, C. H. Nor. I7, I9I6 in upper right corner.

Done from life.

A portrait of the celebrated naturalist.

\section{4 Self-portrait}

$$
\text { I } \times 7 \text { inclies. }
$$

Signed with full name on the screcn.

Done from life and from a similar painting in November, Igr6. 


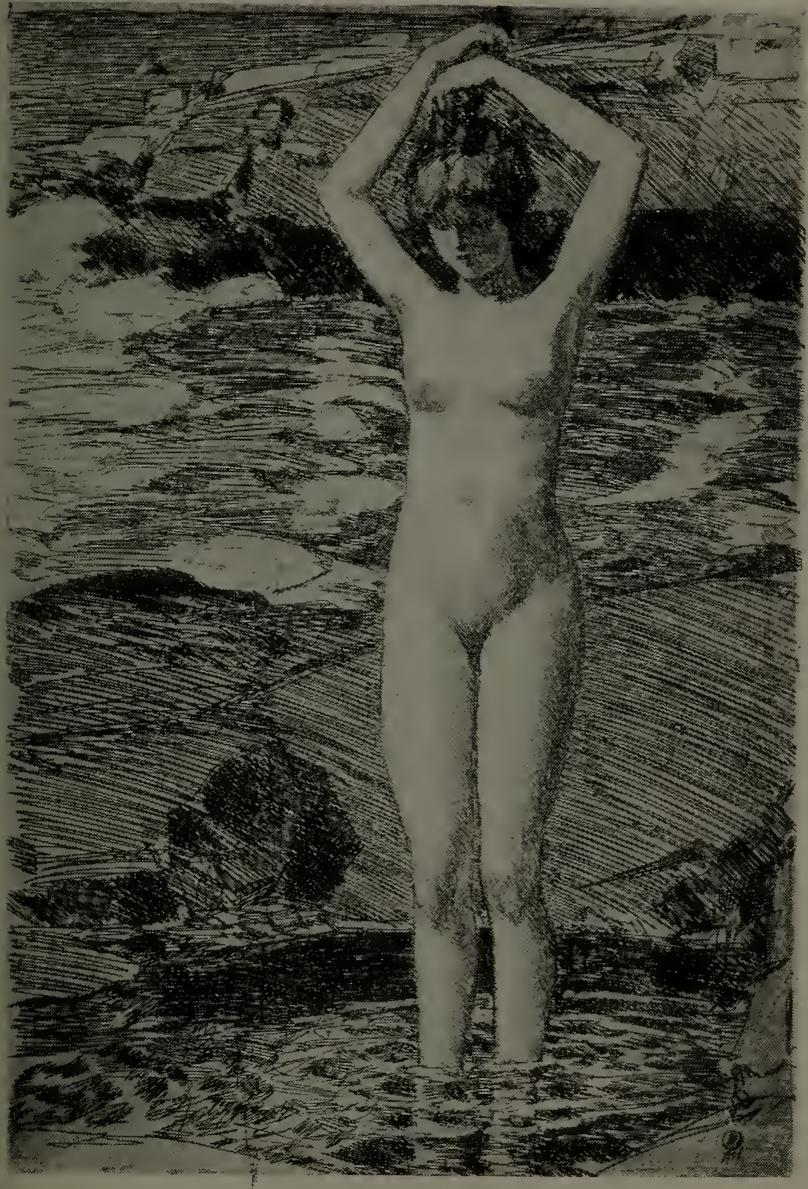

DIANA'S POOL, APPLEDORE 



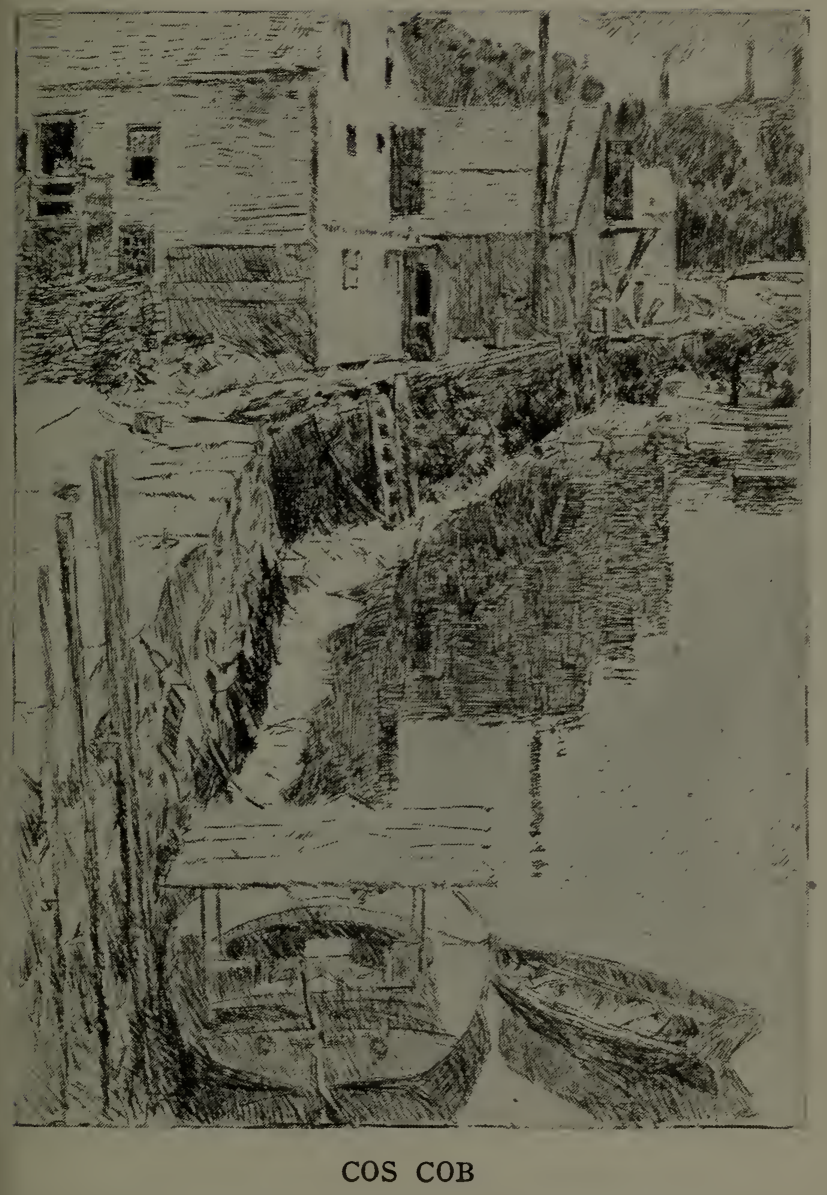




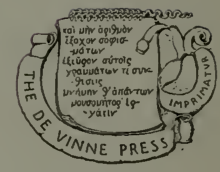




\section{SMITHSONIAN INSTITUTION LIBRARIES}

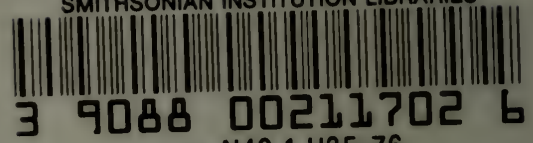

nmaa N40.1.H35yZ6

Childe Hassam : 